\title{
Dialectical analysis of amendment to the Criminal Procedure Law of China in 2018
}

\author{
Peng Haiqing
}

Beijing Institute of Technology,

5, Zhongguancun South Street, Haidian District, Beijing, 100081, People’s Republic of China

For citation: Peng Haiqing. 2021. "Dialectical analysis of amendment to the Criminal Procedure Law of China in 2018". Vestnik of Saint Petersburg University. Law 2: 384-400.

https://doi.org/10.21638/spbu14.2021.209

The amendment to the Criminal Procedure Law in China in 2018 mainly involves enhancing the system for leniency based on admission of guilt and acceptance of punishment, increasing the procedure of fast-track sentencing, improving the convergence norm between the Criminal Procedure Law and the Supervision Law, and adding the procedure for trial in absentia. These improvements and additions have positive implications for the implementation of a criminal policy of leniency and strictness, for realization of the diversion of complex situations and simple situations in the proceedings, for deepening the reform of the state's supervisory system, for realizing the people's procuratorate's effective performance of legal supervision, and power and for effectively punishing crimes of corruption. However, there are limitations in the amendment of the Criminal Procedure Law in 2018. In the future, the amendment to the Criminal Procedure Law can adopt both the comprehensive amendment of the National People's Congress and the partial amendment of its Standing Committee, so as to promote the amendment of the Criminal Procedure Law in a timely and comprehensive manner. In terms of the amendment's content, the judicial reform results and coordination between laws should be fully considered. New regulations for the new law should be clear and enforceable. In regard to law implementation, there should be sufficient time for implementation preparation after the promulgation of the new law.

Keywords: amendment, Criminal Procedure Law, justice and effectiveness, Chinese plea bargaining, trial in absentia, state's supervisory system.

\section{Introduction}

At the sixth session of the Standing Committee of the Thirteenth National People's Congress on October 26, 2018, the decision on amending the Criminal Procedure Law of the People's Republic of China was adopted ${ }^{1}$. This is the third revision of criminal procedure law, which was enacted in 1979 and revised in 1996 and $2012^{2}$, since the founding of the People's Republic of China. Compared with the previous two amendments, the most recent amendment is a "targeted amendment" (Fan Chongyi 2018, 1) and does not imply comprehensive change. But still it is intended to "further improve the criminal proceeding

1 The Criminal Procedure Law, enacted in 2018. Accessed February 17, 2021. http://www.npc.gov.cn/ npc/c12435/201811/59b0fd9941804636b9e403d17d6e3ebf.shtml. (In Chinese)

2 The Criminal Procedure Law, enacted in 1979 and revised in 1996. 2012. Accessed February 17, 2021. https://www.pkulaw.com/chl/e2a1759e436edd66bdfb.html. (In Chinese)

(C) St. Petersburg State University, 2021 
system with Chinese characteristics, deepen judicial reform, promote national governance systems and governance modernization, and is a major revision of the Criminal Procedure Law" (Wang Aili 2018, 1). In addition, the amendment comes only six years after the previous one compared to the interval of 16 years between the first and second amendments. The time interval was significantly shortened to eliminate the allegation that "the criminal procedure law in China is difficult to modify", and it also opens up more possibilities for future revisions of the criminal procedure law in many aspects. This article analyzes the progress and limitations of this amendment to the Criminal Procedure Law, and provides predictions on the future amendment to the criminal procedure law in hopes that it will be beneficial to the development of criminal procedure legislation in China.

\section{Basic research}

\subsection{Main contents and progressiveness of the amendment to the Criminal Procedure Law in 2018}

\subsubsection{Main contents}

\subsubsection{Improve the system for imposing lenient punishments on those who admit to their crimes and accept punishment, and increase the fast-track sentencing procedure}

The leniency system for confessions and punishments is a clear requirement in the Fourth Plenary Session of the Eighteenth Central Committee of the CPC on Several Important Issues Concerning the Comprehensive Advancement of Governing the Country According to $\mathrm{Law}^{3}$. In order to fulfill this requirement, the Standing Committee of the Twelfth National People's Congress on September 3, 2016 adopted "The Decision on Pilot System Work Regulations on Authorizing the Supreme People's Court and the Supreme People's Procuratorate to Carry Out the Pilot Program of Imposing Lenient Punishments on Those Confessing to Their Crimes and Accepting Punishments in Criminal Cases in Certain Areas"'. On November 16, 2016, the Supreme People's Court, Supreme People's Procuratorate, Ministry of Public Security, Ministry of National Security, and Ministry of Justice issued "the Measures for the Pilot Program of Imposing Lenient Punishments on Those Confessing to Their Crimes and Accepting Punishments in Criminal Cases in Certain Areas"5. On December 23, 2017, at the Standing Committee of the thirty-first meeting

3 Several Important Issues Concerning the Comprehensive Advancement of Governing the Country According to Law. Oct. 23 ${ }^{\text {th }}$ 2014. Accessed February 17, 2021. http://cpc.people.com.cn/n/2014/1029/ c64387-25927606.html. (In Chinese)

4 The Decision on Pilot System Work Regulations on Authorizing the Supreme People's Court and the Supreme People's Procuratorate to Carry Out the Pilot Program of Imposing Lenient Punishments on Those Confessing to Their Crimes and Accepting Punishments in Criminal Cases in Certain Areas on September 3, 2016. Accessed Febrary 17, 2021. http://www.npc.gov.cn/wxzl/gongbao/2016-10/12/content_2007460. htm. (In Chinese)

5 The Measures for the Pilot Program of Imposing Lenient Punishments on Those Confessing to Their Crimes and Accepting Punishments in Criminal Cases in Certain Areas. 2016. Accessed February 17, 2021. http://www.jcrb.com/xztpd/2017/jiuyue/sfggzsn_170920/wjzc_0920/8ge/201710/t20171013_1804997. html. (In Chinese) 
of the $12^{\text {th }}$ National People's Congress, Zhou Qiang, the president of the Supreme People's Court, presented "the Interim Report on the Pilot Work of Confession and Punishment in Criminal Cases in Some Regions"6. The report noted that for confession and punishment cases, the average time for review and prosecution by the procuratorial organs is 26 days, and $83,5 \%$ of the cases were concluded by the people's court within 15 days. Fast-tracking sentencing procedures were applied to $68,5 \%$ of cases, $24,9 \%$ had summary procedures applied, and 6,6\% were conducted according to ordinary procedures. The judgment rate in court was 79,8\%, of which 93,8 \% were fast-track cases. By the end of November 2017, a total of 281 pilot courts and procuratorial offices had been identified in the 18 pilot regions, and 91121 criminal cases, 103496 defendants had been concluded under the leniency system for confession, accounting for $45 \%$ of the criminal cases concluded by the pilot courts over the same period. Among them, $98,4 \%$ were recommended by the procuratorate. In October 2017, a research team from China University of Political Science and Law conducted a third-party evaluation of the pilot situation (Zhou Qiang 2017). A total of 1516 lawyers, defendants, and case handlers participated in the survey, and the overall evaluation of the pilot program was relatively high. The lawyer's satisfaction rate was $97,3 \%$ and the defendant's was $94,3 \%$. The pilot shows that the quality and efficiency of handling criminal cases have improved significantly, and it has achieved significant results in implementing the criminal policy of leniency and strictness, ensuring that innocent people are not subject to criminal prosecution and guilty people are punished fairly, safeguarding the lawful rights and interests of the parties, and promoting judicial justice, etc. As a result, the Criminal Procedure Law revised in 2018 absorbed the results of this reform and incorporated it into legislation.

Provisions of the confession and lenient system in Criminal Procedure Law revised in 2018 mainly contain the following contents: first, it addresses Lenient Punishments on Those Confessing to Their Crimes and Accepting Punishments as a basic principle in the Criminal Procedure Law. In other words, Article 15 of the Criminal Procedure Law stipulates that "Where a criminal suspect or defendant voluntarily and truthfully confesses to his or her crime, admits to the facts of the crime that he or she is charged with, and is willing to accept punishment, the criminal suspect or defendant may be granted leniency in accordance with the law". Second, it improves the confession and lenient procedure further. It is mainly reflected in the people's procuratorate hearing opinions on the handling of a case during the review and prosecution stage, the criminal suspect signing a recognizance, the people's procuratorate's proposal for sentencing, the people's court reviewing the voluntariness of confession and the authenticity of the recognizance, etc. Thirdly, the criminal fast-track sentencing procedure has been added. The fast-track procedure has been primarily applied to cases under the jurisdiction of the basic people's courts, in which the defendants, pleading guilty and accepting punishment, may be sentenced up to three years' imprisonment, and the issue of civil compensation has been resolved. Finally, it strengthens the protection of the rights of the parties. Provisions are made on the notification of litigation rights, the establishment of a duty lawyer system, and the explicit use

${ }^{6}$ The Interim Report Concerning the Initiation of the Pilot System of Lenient Punishments on Those Confessing to Their Crimes and Accepting Punishments in Criminal Cases in Some Areas - Standing Committee of the Thirty-first Meeting at the $12^{\text {th }}$ National People's Congress on 23, Dec. 2017, by the Supreme Court Dean, Zhou Qiang. 2017. Accessed February 17, 2021. https://www.chinacourt.org/article/ detail/2017/12/id/3138224.shtml. (In Chinese) 
of confession of guilt and punishment as considerations for assessing social dangers when taking compulsory measures.

\subsubsection{Improve the norms for linking Criminal Procedure Law and the Supervision Law}

In March 2018, the First Session of the Thirteenth National People's Congress ${ }^{7}$ considered and passed the Constitutional Amendment and the Supervision Law. Since then, the reform of the national supervision system has been recognized at the constitutional and legal levels. Therefore, the Criminal Procedure Law needs to adjust relevant provisions to adapt to the provisions of the Constitution and the Supervision Law. Specifically, the relevant changes in the 2018 Criminal Procedure Law are mainly reflected in:

First, it adjusts the scope of cases accepted by the People's Procuratorate. In accordance with the provisions of Paragraph 2, Article 11, of the Supervision $\mathrm{Law}^{8}$, the Supervision Committee investigates illegal duties and duties crimes such as corruption and bribery, abuse of power, neglect of duty, rent seeking, benefit transmission, malpractice for personal gain, and misuse of state funds. On April 17, 2018, the Central Commission for Discipline Inspection and the National Supervision Committee issued the Regulations on the Jurisdiction of the State Supervision Committee (for Trial Implementation) ${ }^{9}$, which outlined 88 crimes in six categories under the jurisdiction of the State Supervision Committee. The six major categories of crimes include: 1) Crimes of corruption and bribery (17 counts); 2) Crimes of abuse of power (15 counts); 3) Crimes of negligence (11 counts); 4) Crimes of malpractice (15 counts); 5) Major accident crime (11 months on charges); 6) Public officials of other crimes (19 months on charges). This requires the Criminal Procedure Law to adjust the scope of cases accepted by the People's Procuratorate. Paragraph 2 of Article 19 of the Criminal Procedure Law revised in 2018 clarifies that the scope of the People's Procuratorate's current cases mainly includes two aspects. The first is when a people's procuratorate discovers that any justice functionary performing statutory duty commits a crime of false imprisonment, extortion of a confession by torture, or illegal search or any other crime that infringes upon a citizen's rights or damages the fair administration of justice by taking advantage of his or her functions, the people's procuratorate may open an official investigation into the crime. The other is in regard to a serious crime committed by any staff member of a government authority by taking advantage of his or her functions under the jurisdiction of a public security authority. This case needs to be directly accepted by a people's procuratorate. The people's procuratorate may open an official investigation into the case upon decision of the people's procuratorate at or above the provincial level.

7 Proposal of the Standing Committee of the National People's Congress on submitting the "Amendment to the Constitution of the People's Republic of China (Draft)" and Proposal of the Standing Committee of the National People's Congress on submitting for deliberation the "Supervision Law of the People's Republic of China (Draft)", March 4, 2018. Accessed February 17, 2021. http://www.npc.gov.cn/npc/ c30834/201803/ce9c51c278f24ebab91b2178a4498404.shtml. (In Chinese)

8 The Supervision Law on March $20^{\text {th }}$, 2018. Accessed February 17, 2021. http://www.npc.gov.cn/ zgrdw/npc/xinwen/2018-03/21/content_2052362.htm. (In Chinese)

9 The Regulations on the Jurisdiction of the State Supervision Committee (for Trial Implementation). 2018. Accessed February 17, 2021. http://www.ccdi.gov.cn/yaowen/201811/t20181123_183903.html. (In Chinese) 
Based on the revision of the scope of the cases dealt with by the people's procuratorate, the investigative powers of the people's procuratorate have also been adjusted accordingly. Firstly, this applies to the application of technical investigation measures by the people's procuratorate. Paragraph 2, Article 150 of Criminal Procedure Law revised in 2018 deleted the power of the people's procuratorate concerning the technical investigation of corruption and bribery cases, it stipulates that "After opening a case regarding a serious crime that gravely infringing upon the personal rights of citizens by taking advantage of one's functions, a people's procuratorate may, as needed for criminal investigation, take technical investigation measures after undergoing strict approval formalities, and request the relevant authorities to execute such measures according to applicable provisions". Second, powers adjusted are seen with the restrictions on meeting criminal suspects during the investigation stage. When the Criminal Procedure Law revised in 2018 stipulated restrictions on meeting criminal suspects during the investigation stage, the words "particularly serious bribery crimes" in the Criminal Procedure Law of 2012 were deleted, and in paragraph 3, Article 39, it stipulated that "When a defense lawyer files a request for a meeting with a criminal suspect in custody during the period of criminal investigation in a case regarding a crime of compromising national security or terrorist activities, the meeting shall be subject to the permission of the criminal investigation authority. In such a case, the criminal investigation authority shall issue a prior notice to the jail. Third, the revision of investigative powers affects the scope of applying surveillance of a residence. In the Criminal Procedure Law revised in 2018, when specifying the scope of application of designated surveillance residence, the words "extraordinarily significant bribery crimes" in the Criminal Procedure Law of 2012 was deleted, and paragraph 1, Article 75, stipulated that "Where the execution of residential confinement at the residence of a criminal suspect or defendant suspected of compromising national security or terrorist activities may obstruct criminal investigation, it may be executed at a designated residence with the approval of the public security authority at the next higher level”.

Second, changes in the 2018 Criminal Procedure Law clarified the norms for the relationship between the People's Procuratorate and the Supervisory Committee in the examination and prosecution process. These norms mainly include, first, the People's Procuratorate returned the cases to supplementary investigations. According to the provisions of Article 45 of the Supervision Law, in case of suspected duty crimes where the supervisory authority finds that the facts are clear, and the evidence is solid and sufficient, the case shall be transferred to the procuratorate for review and prosecution. According to article 170 of the Criminal Procedure Law revised in 2018, the People's Procuratorate has the power to return the cases to supplementary investigations and supplementary investigations on its own in cases transferred by the supervisory committee. The second addresses the connection between compulsory measures and liens. In Article 170, a people's procuratorate shall, in accordance with the relevant provisions of this Law and the Supervision Law, examine a case transferred by the supervisory authority for prosecution. If, upon examination, the people's procuratorate deems further substantiation necessary, it shall return the case to the supervisory authority for further investigation. However, when necessary the people's procuratorate may conduct further investigation itself. Where the supervisory authority has held a criminal suspect in custody in a case transferred to a people's procuratorate for prosecution, the people's procuratorate shall first detain the criminal suspect, and the holding measures taken by the supervisory authority shall be 
automatically removed. The people's procuratorate shall, within ten days after detention, make a decision on whether to arrest or grant bail to the detainee or place the detainee under residential confinement. Under special circumstances, the time limit for making the decision may be extended by one to four days. The period for the people's procuratorate to decide on a compulsory measure shall not be included in the period of examination and initiation of prosecution.

In addition, given that the Supervisory Committee is vested with investigative powers in the Supervision Law, when the meaning of "investigation" was defined in the Criminal Procedure Law revised in 2018, the term "special investigation" used in the definition of "investigation" in the 2012 Criminal Procedure Law was removed. In the first paragraph of Article 108, it stipulates "criminal investigation" means the work of collecting evidence and ascertaining the facts of a case conducted, and the related compulsory measures taken, by public security authorities and people's procuratorates in accordance with the law in handling criminal cases.

\subsubsection{Add procedures for trial in absentia}

The report of the $18^{\text {th }}$ National Congress of the Communist Party of China (CPC) proposes to adhere to the road of anti-corruption with Chinese characteristics, and comprehensively promote the construction of a system of punishment and prevention of corruption (Hu Jintao 2012). In 2017 five years had passed since China's $18^{\text {th }}$ National Congress of the Communist Party of China punished corruption. Until December 2017, as many as 313 pieces of official crime information was published in the Supreme People's Procuratorate's official website, of which 25 new officials at the provincial and ministerial levels or above were newly investigated and 18 prosecutions were filed. Up until October 2017, China had recovered the flight of personnel totaling 3587 people, recovered stolen money totaling 9541 billion yuan from more than 90 countries and regions. In the international pursuit of stolen crimes, from September 2014 to September 2017, procuratorial organs repatriated and persuaded 216 suspects of absconded crimes from 40 countries and regions ${ }^{10}$. In fact, since China ratified and signed the United Nations Convention against Corruption in $2005^{11}$, domestic discussions and appeals for the establishment of a system for trial in absentia gradually started. In 2014, a meeting of the Central AntiCorruption Coordination Group ${ }^{12}$ created the task of establishing a system for trial in absentia. In July 2016, the Legal Work Committee of the Standing Committee of the National People's Congress presented a research report on establishing a system for trial in absentia $^{13}$. The revisions to the law in 2018 established the system for trial in absentia at

10 "It demonstrates commitment to anti-corruption that the Laid-off senior officiala intensively entered into judicial proceedings - 39 'tigers' jailed for creating the highest records since the eighteen national congress”. 2017. Făzhi Ribào. Accessed February 17, 2021. http://fanfu.people.com.cn/n1/2017/1221/ c64371-29720172.html. (In Chinese)

11 The United Nations Convention against Corruption. Accessed February 17, 2021. https://www. un.org/zh/issues/anti-corruption/uncac.shtml. (In Chinese)

12 Strengthen overseas pursuit of fugitives, China plans to amend the law to establish a criminal default trial system. 2018. Accessed February 17, 2021. http://www.ccdi.gov.cn/yaowen/201804/t20180425_170713. html. (In Chinese)

13 Fairness and justice are never absent focus on the criminal system of trial by default. 2018. Accessed February 17, 2021. http://www.ccdi.gov.cn/yaowen/201810/t20181026_182194.html. (In Chinese) 
the legislative level, which is of great significance to earnestly intensify the fight against corruption, safeguard national security, establish judicial authority, and improve the efficiency of litigation. Additionally, the 2018 revisions added a system for trial in absentia as the third chapter in Part V, including 7 new articles from Articles 291 to 297. It mainly includes the following three components:

Firstly, it is clear to whom trials in absentia are applicable and three instances are identified: 1) "When the criminal suspect or defendant is outside China in a case regarding a crime of embezzlement or bribery, or in a case regarding a crime of seriously compromising national security or terrorist activities that requires a timely trial as confirmed by the Supreme People's Procuratorate. If the supervisory authority or public security authority transfers the case for prosecution, and the people's procuratorate deems that the facts of the crime have been substantiated, the evidence is definitive and sufficient and the criminal suspect or defendant shall be held criminally liable in accordance with the law - it may file a public prosecution with the people's court. After examination, the people's court shall decide to hold a court session to hear the case if the facts of the crime alleged in the criminal complaint are clear and the conditions for the application of the procedure for trial in absentia are met"; 2) "When the defendant is unable to appear before court for suffering a serious illness, and trial is suspended for more than six months. If the defendant is still unable to appear before court, and the defendant or his or her legal representative or close relative applies for or agrees to the resumption of the trial - the people's court may try the case in absentia without the defendant's presence in court, and render a judgment in accordance with the law"; 3) "When the defendant dies, the people's court shall rule to terminate the trial. However, if there is any evidence proving the innocence of the defendant, and the people's court confirms his or her innocence by trial in absentia, it shall render a judgment in accordance with the law". Also, "When the defendant dies in a case retried by a people's court under the trial supervision procedures, the people's court may try the case in absentia, and render a judgment in accordance with the law" 14 .

Secondly, the revisions in 2018 clarify the specific procedures for absentia trials where criminal suspects and defendants abscond abroad. It mainly includes jurisdiction, service, judgment, handling of property involved in the case, and delivery and execution of penalties.

Thirdly, provisions on the protection of rights are elucidated. It mainly provides for entrusted defense and the provision of legal aid and grants the close relatives of the defendant the right to appeal and the criminal the right to object.

\subsubsection{Progressiveness}

2.1.2.1. Contributes to the implementation of the criminal policy of combining punishment with leniency, achieve the separation of complicated cases from simple ones, and optimize judicial resource allocation

As mentioned earlier, revisions to the Criminal Procedure Law in 2018 establishes "imposing Lenient Punishments on Those Confessing to Their Crimes and Accepting

14 The Criminal Procedure Law, enacted in 2018. Accessed February 17, 2021. http://www.npc.gov.cn/ npc/c12435/201811/59b0fd9941804636b9e403d17d6e3ebf.shtml. (In Chinese) 
Punishments" as a basic principle, and further revises and improves relevant procedural provisions to make it fulfill its role more completely. The establishment and improvement of it, on the one hand, further implemented the criminal policy of combining punishment with leniency, and perfected the criminal procedure, ensuring that innocent people are not subject to criminal prosecution, guilty people are punished fairly, safeguarding the lawful rights and interests of the parties, and promoting judicial justice. According to the Interim Report on the Pilot Work of the Criminal Plea and Punishment System in Some Areas provided by the President of the Supreme People's Court ${ }^{15}$, from January to September in $2019,9,1 \%$ of cases in which the defendant pleaded guilty were not prosecuted, $1,3 \%$ were exempted from criminal punishment, $36,6 \%$ were sentenced to probation, $2,1 \%$ were sentenced to control, there was one additional sentence, non-custodial coercive measures and the proportion of non-custodial sentences applied has been further increased. On the other hand, the establishment of the principle of imposing Lenient Punishments on Those Confessing to Their Crimes and Accepting Punishments helps to promote the rational allocation of judicial resources, improves the quality and efficiency of handling criminal cases, and achieves the separation of complicated cases from simple ones. According to the above report, from January to September in $2019,14,5 \%$ of guilty and punishment confession cases had ordinary procedures applied; $49,8 \%$ had simplified procedures; and $35,6 \%$ had fast-track sentencing procedures applied.

2.1.2.2. Assists in enhancing the reform of the national supervision system and results in the effective implementation of legal supervision by the People's Procuratorate

In March 2018, the First Session of the Thirteenth National People's Congress considered and passed the Constitution Amendment Act ${ }^{16}$ and the Supervision Law ${ }^{17}$. This is legislative confirmation and affirmation of the results of the reform of the national supervisory system, marking the basic establishment of a new supervisory system in China. The reform of the national supervisory system has entered a new stage of development. The significance of the reform of the national supervisory system is to transfer the duty crime investigation functions and institutions of the procuratorial organs to the supervisory committee. Revision of the law in 2018 conformed to the trend of the reform of the supervision system in China. It made detailed provisions on the connection between the Supervision Law and the Criminal Procedure Law in terms of jurisdiction, coercive measures, review and prosecution, etc., clarifying the working authority and distinction between the procuratorate and the supervisory authority, and realizing the aim that the procuratorate can effectively perform its legal supervision functions.

${ }^{15}$ The Interim Report on the Pilot Work of the Criminal Plea and Punishment System in Some Areas given by the President of the Supreme People's Court, Zhouqiang, at the $31^{\text {st }}$ meeting of the Standing Committee of the $12^{\text {th }}$ National People's Congress on December 23, 2017. Accessed February 17, 2021. https://www.chinacourt.org/article/detail/2017/12/id/3138224.shtml. (In Chinese)

16 The Constitution Amendment Act. 2018. Accessed February 17, 2021. http://www.npc.gov.cn/npc/ c30834/201803/9ba19e7281a34414962c8762e54c87e8.shtml. (In Chinese)

17 The Supervision Law on March $20^{\text {th }}$, 2018. Accessed February 17, 2021. http://www.npc.gov.cn/ zgrdw/npc/xinwen/2018-03/21/content_2052362.htm. (In Chinese) 
2.1.2.3. Helps to strengthen the international search for those who have fled abroad and in recovering ill-gotten gains, and effectively punish corruption crimes

Since 2018, the amendment to the Constitution and the promulgation of the Supervision Law have redefined the pattern of anti-corruption work. However, there are still many problems in the implementation of anti-corruption laws and regulations, which have affected the in-depth development of the anti-corruption fight to a certain extent, which undoubtedly becomes a major regret for the anti-corruption international search for those who have fled abroad and in recovering ill-gotten gains. The law revised in 2018, according to the current status of China's anti-corruption work, added a trial in absentia system to provide strong judicial guarantees for anti-corruption work. Except for some institutional deficiencies and deficiencies that still exist when searching for those who have fled abroad and in recovering ill-gotten gains overseas, legislation has been perfected, which is in line with the intent of the Party 's central committee with Comrade Xi Jinping as its core to make major strategic efforts in anti-corruption and the international search for those who have fled abroad and in recovering ill-gotten gains, and it is helpful to effectively punish corruption crimes.

\subsection{Limitations of the amendments to the Criminal Procedure Law in 2018}

\subsubsection{Failure to fully absorb the Results of judicial reform}

\subsubsection{The rule of exclusion of illegal evidence is not fully reflected}

Since the implementation of the Criminal Procedure Law revised in 2012, the practical effect of the exclusionary rules of illegal evidence is not optimistic. Not only is there a theoretical controversy over the rules themselves, but the cases that are effectively applied in practice are also quite limited. For example, according to the Shanghai High Court's Investigation Report on the Exclusion of Illegal Evidence ${ }^{18}$, from 2012 to 2016, the Shanghai court system found a total of 167864 criminal cases, of which 242 cases applied for exclusion of illegal evidence, accounting for $0,14 \%$ of the total number of cases. Later, 170 cases of illegal evidence exclusion procedures were actually initiated, and 16 cases were finally identified and excluded. The number of initiated cases accounted for 70,2\% of the number of applications, and the number of cases that actually excluded illegal evidence accounted for $6,6 \%$ of the number of applications. Furthermore, the exclusion of illegally obtained evidence has little impact on the final verdicts. In the 16 cases that excluded illegal evidence, no one was declared not guilty or had penalty waived (Guo Weiqing et al. 2018). For this reason, on April 18, 2017, the "Central Issues on Strict Exclusion of Illegal Evidence in Criminal Cases" was approved at the $34^{\text {th }}$ Meeting of the Leading Group of the Central Committee for Comprehensive and Deepening Reform. Responding to the actual problems in the targeted positive response, many regulations are "stricter" (Bian Jianlin, Xie Shu 2017, 16), including defining the scope of illegal speech evidence even further,

18 Improving illegal evidence exclusion rules and actively advancing the reform of the litigation systemShanghai Higher Court's Investigation Report on Illegal Evidence Exclusion. 2018. Accessed February 17, 2021. http://www.360doc.com/content/18/0606/11/832246_760082438.shtml. (In Chinese) 
attaching importance to the collection and use of process evidence, further clarifying the mechanism of eliminating repeated confession, the role of the legality of evidence collection in pre-court meetings, etc. In November 2017, the Supreme People's Court also specifically adopted the "People's Court's Procedures for the Elimination of Illegal Evidence in Criminal Cases (Trial)"19 as one of the "Three Directive Procedural Rules"20, detailed its procedures, and implemented it nationwide. However, the amendments to the Criminal Procedure Law in 2018 did not address the content of the exclusionary rules for illegal evidence.

\subsubsection{The relevant results of the reform of the trial-centered criminal procedure system have not been fully reflected}

In October 2014, the Fourth Plenary Session of the Eighteenth Central Committee of the Communist Party of China passed the Decision of the Central Committee of the Communist Party of China on Several Important Issues Concerning the Comprehensive Advancement of Governing the Country According to Law ${ }^{21}$, which requires explicitly to promote the reform of the trial-centered criminal procedure system. On October 11, 2016, according to the provisions of the Constitution and the law, the Supreme People's Court, the Supreme People's Procuratorate, the Ministry of Public Security, the Ministry of National Security, and the Ministry of Justice issued and implemented "Opinions on Promoting the Reform of the Trial-Centric Criminal Procedure System"22. The fundamental purpose of advancing reform of the trial-centered criminal procedure system is to make the handling of each case, by department, attach importance to the decisive role of court trials, strictly enforce evidence standards, implement rules and requirements, and ensure the quality of the case, thereby it can effectively avoid the occurrence of unjust, false and wrong cases, which has a far-reaching and significant impact on the development of China's criminal litigation. However, the revision of the Criminal Procedure Law in 2018 did not include these elements.

\subsubsection{Provisions for listening to opinions from lawyers in capital punishment} cases have not been included in the amendments to the Criminal Procedure Law in 2018

The "Measures on Listening to the Opinions of Lawyers on the Handling of Death Penalty Review Cases" ${ }^{23}$, promulgated by the Supreme People’s Court on January 29, 2015,

19 People's Court's Procedures for the Elimination of Illegal Evidence in Criminal Cases (Trial) on November 2017. Accessed February 17, 2021. https://www.chinacourt.org/article/detail/2018/01/ id/3195237.shtml. (In Chinese)

20 Three Directive Procedural Rules by the Supreme Court. Accessed February 17, 2021. http://www. court.gov.cn/fabu-xiangqing-75652.html. (In Chinese)

21 The Decision of the Central Committee of the Communist Party of China on Several Important Issues Concerning the Comprehensive Advancement of Governing the Country According to Law on October 23, 2014. Accessed February 17, 2021. http://cpc.people.com.cn/n/2014/1029/c64387-25927606. html. (In Chinese)

22 Opinions on Promoting the Reform of the Trial-Centric Criminal Procedure System. Accessed February 17, 2021. https://www.spp.gov.cn/zdgz/201610/t20161011_169052.shtml. (In Chinese)

23 Measures on Listening to the Opinions of Lawyers on the Handling of Death Penalty Review Cases, Accessed February 17, 2021. http://www.court.gov.cn/fabu-xiangqing-13171.html. (In Chinese) 
clearly stipulates the right of lawyers to meet, review and submit opinions during the death penalty review, and provides in detail the procedures concerning submitting legal opinions from lawyers, which is an important step in protecting the rights of lawyers in death penalty review cases. However, the amendment to the Criminal Procedure Law revised in 2018 did not include this content.

\subsubsection{The amendments to the Criminal Procedure Law in 2018 inadequately incorporated specifications for electronic data collection and acceptance}

The Criminal Procedure Law revised in 2012 added electronic data into the type of legal evidence, which further enriched the extension of evidence. With the continuous development of information technology, there has been a rising trend in cybercrime year by year. Electronic forensics has emerged at a historic moment. Its biggest feature is that it can quickly collect effective electronic information. However, while this technology provides us with convenience, it also enables some criminals to use computers to carry out criminal activities. To a certain extent, it not only hinders the pace of electronic data in China, but also poses new challenges for electronic evidence collection. For this reason, on May 4, 2014, the Supreme People's Court, the Supreme People's Procuratorate, and the Ministry of Public Security jointly issued "Opinions on Several Issues concerning the Application of Criminal Procedural Procedures in the Handling of Cybercrime Cases" ${ }^{\text {"24 }}$, Part $\mathrm{V}$ of which clarified the issue of evidence collection and review of electronic data, trying to solve the problems of lack of electronic data extraction, fixation, presentation, identification, cross-examination and other related regulations ${ }^{25}$. However, the revised Criminal Procedure Law of 2018 has not made the corresponding improvements and refinements in the fields of electronic data collection and acceptance.

\subsubsection{Conflicts between the New Procedure and the Original Procedure}

2.2.2.1. The trial procedure in absentia is in conflict with the confiscation procedures for illegal income in cases where a criminal suspect or defendant escapes or dies

The Criminal Procedure Law revised in 2018 established the trial procedure in absentia. However, the introduction of this procedure has caused new problems in the application of confiscation procedures for illegal income in cases where a criminal suspect or defendant escapes or dies. The difference between the trial procedure in absentia and the confiscation procedures for the above-mentioned cases is difficult to make the two procedures compatible with each other while maintaining independence. The reasons are as follows. First, types of cases are different. According to the Supervision Law, it stipulates that the supervisory authority can start the forfeiture proceedings on offenses of corruption, bribery, dereliction of duty and other crimes. The revised law in 2018 specifically covers

${ }^{24}$ Opinions on Several Issues concerning the Application of Criminal Procedural Procedures in the Handling of Cybercrime Cases. Accessed February 17, 2021. https://www.spp.gov.cn/zdgz/201407/ t20140707_75916.shtml. (In Chinese)

${ }^{25}$ Law and Policy Research Office of the Supreme People's Procuratorate. 2014. "Understanding and Application of Views on a Number of Issues Dealing with the Cases of Cybercrime Applicable Criminal Procedure”. Rénmín Jiănchá 14: 25-29. (In Chinese) 
the scope of trials in absentia as corruption and bribery crimes, crimes against national security, and crimes of terrorist activities, excluding 61 counts of negligence and malfeasance under the jurisdiction of the supervisory authority (Qi Jianping 2018). Second, the applicable conditions are different. There are three conditions for the supervision agency to initiate the confiscation procedure: during the supervision and investigation process it is necessary to continue the investigation, with the approval of the supervisory organ at or above the provincial level, the investigation shall be continued, and a conclusion shall be made. If the person under investigation has escaped and cannot be arrested after being listed as wanted for one year, or is dead, the basis for trial in absentia is absconding abroad. Third, the certification standards differ. In 2017, the Supreme People's Procuratorate and Supreme People's Court issued the "Provisions on Several Issues concerning the Application of the Confiscation Procedures for Illegal Income in a Case Where a Criminal Suspect or Defendant Escapes or Dies"26, which detailed the burden of standards for the confiscation procedures for illegal income. It adopts the standard of "there is evidence to prove the facts of a crime" for the review of evidence of a suspected crime and adopts the "high possibility" standard of the connection between the application of confiscation of property and crime. However, the trial in absentia involves activity as in a real criminal trial. The standard of proof is consistent with the ordinary criminal procedure. The review of crime and the nature of the property involved in the case must be carried out simultaneously, and both need to meet the standard of "evidence is hard and sufficient". Fourth, foreign documents are served in different forms. The situation of special confiscation procedures for illegal income for overseas delivery is relatively flexible. The legal and mandatory procedures are public announcements. Once announced, the right to know the procedure of expatriates is protected by default. Different from the service of confiscation procedure, the delivery of documents to a specific person is a prerequisite for trial in absentia. There are three methods of service: mutual legal assistance, diplomatic service, and other methods permitted by the law of the recipient's location.

\subsubsection{The convergence provisions of the new criminal procedure law and the supervision law are not established}

Article 4 of the Supervision Law stipulates that: "Supervisory organs shall handle the cases of duty violations and duty crimes in cooperation with judicial organs, procuratorial organs and law enforcement agencies, and restrict each other". However, when the Criminal Procedure Law revised in 2018 was amended, the principle of division of responsibilities, coordination, and mutual restraint among the three organs in the procedural law has not been modified.

\subsubsection{Clarity and enforceability of the new law's content}

In this amendment, the newly added trial in absentia system has provided clear and enforceable rules for the trial procedures of absconding and embezzlement crimes, serious

26 The provisions of the Supreme People's Court and the Supreme People's Procuratorate on Several Issues Concerning the Application of Procedures for Confiscating Illegal Income of Criminal Suspects and Defendants, Accessed February 17, 2021. https://www.spp.gov.cn/zdgz/201701/t20170106_177669.shtml. (In Chinese) 
crimes against national security, and terrorist crimes. The trial procedure of the defendant who is ill or dead is unclear and will obviously cause difficulties in its implementation.

\subsubsection{No implementation preparation time is reserved after the modification}

The enactment of the first criminal procedure law after the founding of the People's Republic of China and the subsequent announcement of the two amendments in 1996 and 2012 were 5 to 9 months apart from the implementation of the new law. For example, the first criminal procedure law after the founding of the People's Republic of China was reviewed and approved by the Second Session of the Fifth National People's Congress on July 1, 1979, announced on July 7, and implemented on January 1, 1980. On March 17, 1996, the Fourth Session of the Eighth National People's Congress considered and formally adopted the Decision on Amending the Criminal Procedure Law of the People's Republic of China. The revised Criminal Procedure Law has been in force since January 1, 1997. The "Decision on Amending the 'Criminal Procedure Law of the People's Republic of China'" was adopted at the Fifth Session of the Eleventh National People's Congress on March 14, 2012, and came into effect on January 1, 2013. There is a certain time interval between the promulgation and implementation of the new law, which is to allow judicial practitioners to recognize, be familiar with, understand, and apply the new law, thereby ensuring the smooth implementation of the new law. The amendments to the Criminal Procedure Law were passed on October 26, 2018 and came into effect on the date of publication. This practice, which was implemented from the date of promulgation of the legislation, is the first in the history of the criminal procedure law legislation, and it will inevitably be an inconvenience to the implementation of the new law.

\subsection{Prospects for future amendments to the Criminal Procedure Law}

\subsubsection{Methods of modifications}

The Criminal Procedure Law is a basic law. It was enacted in 1979, and then two major amendments were made in 1996 and 2012. Both were reviewed and approved by the National People's Congress. After analysis, this amendment is clear and specific. It is precise and limited in scope and does not involve the modification of the basic principles of the Criminal Procedure Law. According to the relevant provisions of the constitution and the legislative law, it is planned to refer to the previous practice of amending the Civil Procedure Law and Administrative Procedure Law, that is, the Standing Committee of the National People's Congress will partially supplement the Criminal Procedure Law and the amendments do not need to be submitted to the National People's Congress for consideration (Shen Chun Yiao 2018, 748). There are different views in academic circles as to whether this modification adopted by the 2018 Criminal Procedure Law is desirable. For example, some scholars believe that the Criminal Procedure Law has just undergone major changes in 2012. It is obviously unrealistic to make major changes again through the National People's Congress within a few years. At the same time, other scholars believe that amendments to the law in the form of amendments will inevitably have limitations (Wang Min Yuan 2019, 4). In my opinion, we can weigh the advantages and disadvantages for analysis. In terms of advantages, this modification method highlights the "timeliness" 
of the amendment. The Standing Committee of the National People's Congress is a permanent organ of the National People's Congress, the highest organ of state power in the People's Republic of China - one whose responsibilities is to partially supplement and revise laws formulated by the National People's Congress during the intercessional period. However, the amendment must not conflict with the basic principles of the law. Social development is advancing rapidly, and the amendments to the law by the Standing Committee of the National People's Congress can, to a certain extent, solve the predicament of untimely amendments to the law during the intercessional period of the National People's Congress to meet the social reality in a timely manner. As pointed out by Professor Bian Jianlin, "The task of the first meeting of the Thirteenth People's Congress held in March 2018 was significant, it reviewed and approved the amendments to the Constitution and the Supervision Law, and revision of the Criminal Procedure Law therefore was not on the agenda. However, because it is in line with the spirit of the constitution and is effectively connected with the Supervision Law, the amendment of the Criminal Procedure Law is urgent. Therefore, the Standing Committee of the National People's Congress has chosen to amend it, that is, adopt the "amendment model" (Bian Jianlin 2018, 83). In terms of disadvantages, incompleteness is also obvious. After all, the Standing Committee of the National People's Congress is a permanent institution of the National People's Congress, with limited work functions and abilities, and it has a short preparation time. Its additions and amendments to the law are destined to be of an emergency nature and difficult to comprehend. Therefore, in the author's opinion, the future revision of the Criminal Procedure Law can take the form of both a comprehensive revision of the National People's Congress and a part of its Standing Committee, so as to promote the revision of the Criminal Procedure Law in a timely and comprehensive manner.

\subsubsection{Contents of modifications}

\subsubsection{Fully consider the results of judicial reform}

Since the $18^{\text {th }}$ CPC National Congress, the Central Committee with Comrade Xi Jinping at the head has made major preparations for comprehensively administering the country according to law and comprehensively deepening the reform of the judicial system. The main body of reform with the nature of "four beams and eight pillars" has been fundamentally established. The judiciary is at the forefront of the practice. It is the first to understand the need for practice and the lack of legislation. New reforms in the field of criminal justice are constantly being introduced. The phenomenon of "judicial rules first, legislation follow up" in the construction of the rule of criminal law will exist for some time. Therefore, future amendments to the criminal procedure law should fully pay attention to the results of judicial reform, consist of a timely review and summarize the effective judicial reform experience, and incorporate it into legislation. Reforms such as the trial-centered rule and exclusionary rules for illegal evidence mentioned above should be incorporated into legislation as soon as possible.

\subsubsection{Fully consider the coordination between different laws}

From the scientific perspective of legislation, the principles, systems, and procedures involved in the criminal procedure law should be logically self-consistent. As part of our 
legal system, the criminal procedure law and other laws must not contradict each other. If there is such a contradiction in legislation, there is no doubt that it will hinder the implementation of legislation. For example, the conflict between the trial in absentia procedure and the confiscation procedure described above, the differences between the three organs relationship principle in the Criminal Procedure Law and the three organs relationship principle in the Supervision Law, etc., must be rationalized in future amendment of the criminal procedure law, in order to ensure criminal proceedings are implemented in accordance with the legislative intent.

\subsubsection{The new provisions of the new law should be clear and enforceable}

The newly revised law generally includes increasing, changing, abolishing and other content, among which the new contents are a concentrated expression of the voice of the judicial practice. They are vital to solve the problem of judicial practice and will gain attention and a practical focus in the implementation process of the new law. If these new regulations are unclear and weakly enforceable, it will obviously affect the overall implementation of the new law. Therefore, when the criminal procedure law is revised in the future, the new provisions should be clear and enforceable. Otherwise, after the new law is promulgated, it can only be supplemented by judicial interpretation. For example, the Supreme People's Procuratorate, the Ministry of Public Security, the Ministry of National Security, and the Ministry of Justice jointly issued the Guidelines on the Application of Pleniency and the Pleniency System ${ }^{27}$ on October 24, 2019 to implement the revised Criminal Procedure Law and ensure the correct and effective implementation of the leniency and confession system. Another example is that the Supreme People's Procuratorate issued the revised "Criminal Procedure Rules of the People's Procuratorate"28 on December 30, 2019, and the Ministry of Public Security issued the revised "Procedural Regulations for the Handling of Criminal Cases by Public Security Organs"29 on July 20, 2020, which respectively regulates the application of the revised criminal procedure law by the People's Procuratorate and public security organs.

\subsubsection{Preparations for the Implementation of the New Law}

After the amendment and promulgation of the Criminal Procedure Law, appropriate preparation time should be set aside. On the one hand, there is time to develop an interpretation of the applicable criminal procedure law. Practice has shown that interpretation of the application of the criminal procedure law by the Ministry of Public Security, the Supreme People's Court and the Supreme People's Procuratorate is usually in the new

27 The Guidelines on the Application of the Pleniency and Pleniency System, Issued by the Supreme People's Procuratorate, the Ministry of Public Security, the Ministry of National Security, and the Ministry of Justice on October 24, 2019. Accessed February 17, 2021. http://rmfyb.chinacourt.org/paper/html/201910/25/content_161544.htm?div=-1. (In Chinese)

28 Criminal Procedure Rules of the People's Procuratorate, by the Supreme People's Procuratorate. Accessed February 17, 2021. http://www.npc.gov.cn/npc/c30834/201912/17d394b71e3a4db581d221e477c9 300f.shtml. (In Chinese)

29 Procedural Regulations for the Handling of Criminal Cases by Public Security Organs, issued by Ministry of Public Security on July 20, 2020. Accessed February 17, 2021. http://www.cpd.com.cn/n1695/ n3559/202008/t20200815_926572.html. (In Chinese) 
law released before or at the time of implementation. However, the interpretation of the Criminal Procedure Law revised in 2018 from the Supreme People's Procuratorate was released on December 30, 2019, interpretations from the Ministry of Public Security released on July 4, $2020^{30}$, and the interpretations from the Supreme People's Court released on December 7, 202031. The issuance of interpretations obviously results in difficulties for judicial practice. On the other hand, there is time for practitioners to learn about the content of the new law and master its content, while the editing and publishing of teaching materials and the organization of training courses also require time.

\section{Conclusions}

Since its promulgation in 1979, the Criminal Procedure Law has undergone three revisions, each of which has caused widespread concern in the academic community. Since the promulgation and implementation of the Criminal Procedure Law on October 26, 2018 , it the rules formed by the previous amendments to the criminal procedure law were subverted. No matter the speed of the amendment and its promulgation, or the scope of the amendment, it presents unique features. Analysis and reflection are undoubtedly of great significance for the future amendment of criminal procedure law. In any case, it is firmly believed that with the development of the times and the deepening of the development of the socialist rule of law, the future revision of the criminal procedure law will make greater progress in terms of science and democracy.

\section{References}

Bian, Jianlin, Xie Shu. 2017. "Illegal Evidence Exclusion Rule is a Major Development — From the Perspective of Promulgation of 'Rigorous Exclusion of Illegal Evidence Regulations"'. Zhéjiāng Gōngshāng Dàxúe Xúebào 5: 15-22. (In Chinese)

Bian, Jianlin. 2018. "Interpretation and Reflection - Revision of the Criminal Procedure Law". Zhōnggòng zhōngyāng Dăngxiào Xúebào 6: 78-84. (In Chinese)

Fan, Chongyi 2018. "Interpretation of the Latest Amendments to the Criminal Procedure Law in 2018". Zhōngguó Fălù 6: 1-12. (In Chinese)

Guo, Weiqing, Zhang Xin, Shen Pinpei, Ye Qi, Chen Chundan, Zhang Neng. 2018. "Improving the Rules for the Exclusion of Illegal Evidence and Actively Promoting the Reform of the Litigation SystemShanghai High Court's Investigation Report on the Exclusion of Illegal Evidence". Accessed December 17, 2020. http://www.360doc.com/content/18/0606/11/832246_760082438.shtml. (In Chinese)

$\mathrm{Hu}$ Jintao. 2012. "Unswervingly advance along the road of socialism with Chinese characteristics and strive to build a well-off society in an all-round way - Report at the $18^{\text {th }}$ National Congress of the Communist Party of China". Accessed February 17, 2021. http://www.wenming.cn/djw/szxxpt/ zyjs/201307/t20130709_1336840.shtml. (In Chinese)

Qi, Jianping. 2018. "Discrimination of Illegal Proceedings and Absent Trial Procedures for Duty Crimes". Rénmín Făyuànbào. Accessed February 17, 2021. http://rmfyb.chinacourt.org/paper/html/202102/11/node_2.htm. (In Chinese)

Shen Chun, Yiao. 2018. Explanations About "People's Republic of China Criminal Procedure (Amendment)" at

${ }^{30}$ Decision of the Ministry of Public Security on Amending the Provisions on the Procedures for Handling Criminal Cases by Public Security Organs (Order No. 159 of the Ministry of Public Security). Accessed February 17, 2021. https://www.mps.gov.cn/n6557558/c7303753/content.html. (In Chinese)

${ }^{31}$ Interpretation of the Supreme People's Court on the Application of the "Criminal Procedure Law of the People's Republic of China". Accessed February 17, 2021. http://www.court.gov.cn/fabu-xiangqing-286491.html. (In Chinese) 
the Second Session of the Standing Committee of the Thirteenth National People's Congress on April, 25 2018. Beijing, Law Press. (In Chinese)

Wang, Aili. 2018. Interpretation of the Criminal Procedure Law of the People's Republic of China. Beijing, Law Press. (In Chinese)

Wang, Min Yuan. 2019. "Discussion on Key Issues of Criminal Procedure Law Amendment”. Făzhì Yánjiū 2: 3-12. (In Chinese)

Zhou Qiang. 2017. "Mid-term Report on the Pilot Work of the Criminal Plea Confession System in some Areas, at the $31^{\text {st }}$ Meeting of the Standing Committee of the $12^{\text {th }}$ National People's Congress on December 23, 2017”. Accessed December 17, 2020. https://www.chinacourt.org/article/detail/2017/12/ id/3138224.shtml. (In Chinese)

Received: September 7, 2020 Accepted: March 15, 2021

Author's information:

Peng Haiqing — PhD of Law; haiqingpeng2013@163.com 